\title{
De SGBO: 60 jaar jong!
}

Marjolein Bastiaanssen, Frank Moret en Joost van der Gulden

\begin{abstract}
Het begin
Op 19 september 1960 startte de Basiscursus sociale geneeskunde aan de Radboud Universiteit. Initiatiefnemer was prof. Mertens, destijds de hoogleraar Sociale geneeskunde. De opleiding tot sociaal geneeskundige bestond toen uit een A-deel, de gemeenschappelijke basis voor de opleiding tot bedrijfsarts, verzekeringsgeneeskundige en arts $M \& G$, en een gespecialiseerd B-deel als vervolg. Vanaf april 1964 was het mogelijk ook de B-opleiding tot bedrijfsarts in Nijmegen te volgen. Fons Vernooy berichtte uitgebreid in TBV over de ontstaansgeschiedenis van de SGBO bij het 50 jarig jubileum. ${ }^{1}$ Een belangrijke gebeurtenis in de laatste 10 jaar was de start van de opleiding tot verzekeringsarts in 2014.
\end{abstract}

\section{Flinke groei}

Over de jaren heen kende de bedrijfsartsenopleiding een wisselende belangstelling. $\mathrm{Na}$ een dip is de instroom de afgelopen jaren sterk toegenomen. In september starten cursusgroep 57 en 58 . In de verzekeringartsenopleiding begint groep 7 in december.

Vernooy signaleerde 10 jaar terug dat toen meer jonge artsen aan de opleiding begonnen dan voorheen. Dit patroon heeft zich voortgezet: de gemiddelde leeftijd is verder gedaald. Bovendien stromen nu vooral vrouwen in. Deze ontwikkeling herkennen we in beide opleidingen. ${ }^{2}$ De aios verwachten een serieuze opleiding waarin zij zich kunnen ontwikkelen tot specialist op hun vakgebied. Het gaat om veel meer dan een briefje halen.

We zien nu ook een ruime instroom van klinisch specialisten die bedrijfsarts of verzekeringsarts willen worden. In de bedrijfsartsenopleiding is dit aantal zo groot dat in oktober een speciale zij-instromersgroep start met een verkort programma. Als de hierboven genoemde groepen zijn gestart, zullen er dit najaar zo'n 225 aios en zij-instromers in opleiding zijn bij de SGBO.

Veel meer dan voorheen is er ook aandacht voor de scholing van praktijkopleiders in didactische en agogische vaardigheden.

Marjolein Bastiaanssen is eerstverantwoordelijke instituutsopleider voor de

bedrijfsartsenopleiding.

Frank Moret is eerstverantwoordelijke instituutsopleider voor de

verzekeringsartsenopleiding.

Joost van der Gulden is hoofd van de SGBO.

Correspondentieadres: Joost.vanderGulden@radboudumc.nl

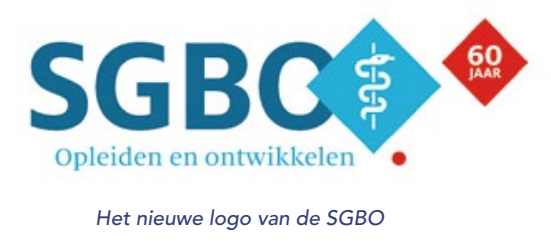

\section{De Jonge Bedrijfsarts, AIOS/ANIOS-netwerk UWV en LOSGIO}

Een groot aantal aios van de SGBO is actief in de netwerken voor jonge artsen in de bedrijfs- en verzekeringsgeneeskunde. Zo zijn zij ambassadeur in de campagne De andere dokter, organiseren zij symposia en geven zij workshops op de Bedrijfsgeneeskundige en Verzekeringsgeneeskundige Dagen. Ook geven zij input aan de wetenschappelijke verenigingen tijdens ledenvergaderingen, evaluatiebijeenkomsten over het Landelijke Opleidingsplan en binnen de opleidingscommissies.

\section{Inhoudelijke vernieuwing}

Gedurende de afgelopen 60 jaar vond een continue vernieuwing van de opleiding plaats om in te spelen op de ontwikkelingen in het vak en de opleidingseisen van de wetenschappelijke verenigingen. Veel meer dan voorheen is er aandacht voor de persoonlijke en professionele ontwikkeling van de aios, zij-instromers en hun praktijkopleiders. Dit stelt ook nieuwe eisen aan het SGBO-team dat is versterkt met een groep gedragswetenschappelijke docenten. Tot begin dit jaar vond een groot deel van het onderwijs in de vaste cursusgroep plaats. De COVID-19-pandemie bracht hierin verandering. Aan het begin van de lockdown is al het contactonderwijs omgezet naar afstandsleren, ondersteund door online sessies (virtual classroom). Uit evaluaties onder de aios blijkt dat dit redelijk tot goed verloopt. Toch hopen we onze aios in het komende jubileumjaar weer wat frequenter te zien op onze cursuslocatie Soeterbeeck in Ravenstein.

Gelet op alle onzekerheid zijn er nog geen grotere jubileumactiviteiten gepland. We hopen dat ook daarvoor binnenkort weer mogelijkheden ontstaan.

\section{Literatuur}

1. Vernooy F. 50 jaar Nijmeegse bedrijfsartsencursus SGBO: op zoek naar de wortels. Tijdschrift Bedrijfs- en Verzekeringsgeneeskunde 2011;19:64-68.

2. Capaciteitsorgaan. Capaciteitsplan 2021-2024. Deel rapport 4 Sociaal Geneeskundigen. Utrecht: Capaciteitsorgaan, 2019. 